\title{
ASEAN Food Reserve and Trade: Review and Prospect
}

\author{
Irfan Mujahid and Lukas Kornher
}

\subsection{Introduction}

High uncertainty and volatility of food prices in the recent years have renewed the interests of many countries in considering food reserves as an important instrument in managing food price instability. These reserves come back into the focus of policy agenda as a result of the huge doubts on the reliability of international trade to guarantee food supply. The 2008 crisis, in particular, highlighted that low levels of food stocks make countries vulnerable to excessive price volatility even only with low levels of supply or demand shocks (Wright 2009).

Countries in Southeast Asia have been using storage-based price stabilization for decades (Rashid et al. 2007). Grain price stabilization in the Philippines started in 1960s, carried out by Rice and Corn Administration (RCA) and Rice and Corn Board (RICOB). In Indonesia, price stabilization is managed by Badan Urusan Logistik (BULOG), a national food reserve agency created in 1967. At the regional level, the cooperation on food reserves has been ongoing since the late 1970s, when the original members of the Association of Southeast Asian Nations (ASEAN) established the Agreement on Food Security Reserve (AFSR). The ASEAN Emergency Rice Reserve (AERR) was created in 1979 with the initial earmarks of 50,000 tons of rice to serve as the subset of national stocks in addressing

I. Mujahid (ه)

Center for Development Research, University of Bonn, Bonn, Germany

e-mail: imujahid@uni-bonn.de

L. Kornher

University of Kiel, Kiel, Germany

(C) The Author(s) 2016 
food emergencies in the region. However, due to small size of the stocks and its complex release mechanism, the AERR had never really been activated during the entire operational period of more than a quarter of a century (Dano 2006).

The recent food price crisis affecting almost all countries in the world led to a new phase of the regional reserve cooperation in Southeast Asia. The ten member countries of ASEAN, in partnership with China, Japan, and Korea, agreed on the ASEAN Plus Three Emergency Rice Reserve (APTERR), which entered into force in July 2012. The APTERR is a permanent reserve scheme which replaces the pilot project East Asia Emergency Rice Reserve (EAERR), which itself was presented as a metamorphosis of the AERR. The initial earmark of APTERR is 787,000 tons of rice, roughly twice the size of von Braun and Torero's (2008) proposal for a modest emergency grain reserve of 300,000-500,000 metric tons for the whole world. However, the APTERR has hardly been tested in practice. Since entering into force, only 200 tons of rice have been released at the end of 2012 for poverty alleviation and the malnutrition eradication program in Indonesia, and another 800 tons of rice in early 2014 for typhoon Haiyan victims in the Philippines. Several other small releases have been made during its pilot phase from 2004 to $2010 .{ }^{1}$

This study aims to review the storage-based price-stabilization policy in Southeast Asia, both at the national and regional level, and to discuss the prospect of the policy in the current era of price instability. The remainder of the article is organized as follows: Sect. 17.2 provides information on ASEAN market structure, which will discuss the food trade and development of trade cooperation in the region. Sections 17.3 and 17.4 describe food reserves at the national and regional level in ASEAN, including a discussion on their cost and benefit. The discussion about food reserves at the national level will use several countries in ASEAN as examples, while at the regional level, the discussion will mainly focus on the ASEAN $+3 .^{2}$ Section 17.5 analyzes the WTO rules on public stockholding, and the last section provides the concluding remarks.

\subsection{ASEAN Food Market Structure}

The recent waves of global food price crisis have affected almost all countries in the world. ASEAN countries are among those that are hit by the price crisis. Since 2007, the food price index increases have been higher than the consumer price index increases in the region (Fig. 17.1).

ASEAN countries accounted for $29 \%$ of the total global rice output in 2013, while maize production in this region accounted only for $4 \%$ of the total global output. Countries in this region are not traditional producers of wheat and other

\footnotetext{
${ }^{1}$ www.apterr.org, accessed on 17 September 2014.

${ }^{2}$ Association of Southeast Asian Nations (ASEAN) members are: Brunei, Cambodia, Indonesia, Laos, Malaysia, Myanmar, Philippines, Singapore, Thailand, Vietnam; Plus Three Countries (+3) are China, Japan, Rep. Korea.
} 


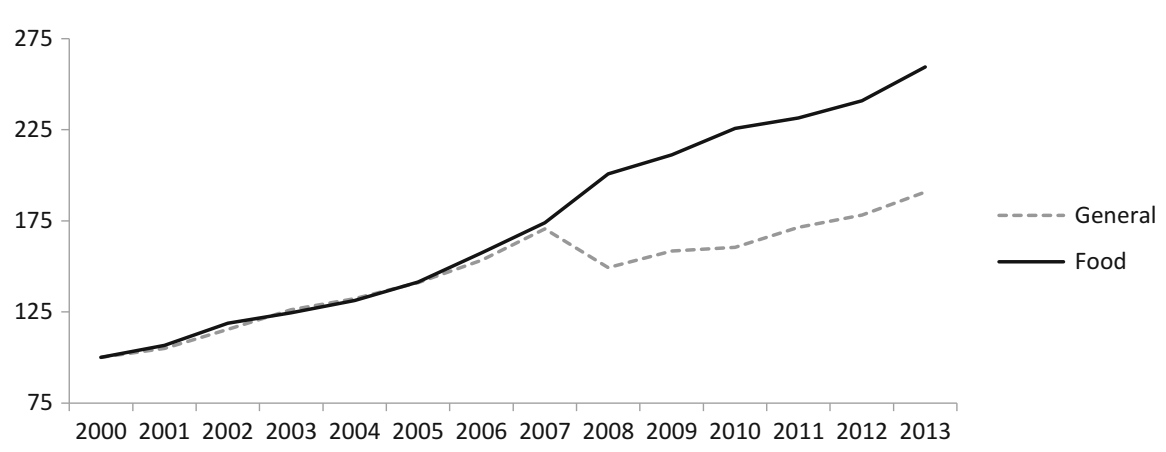

Fig. 17.1 General and food price index in Southeast Asia $(2000=100)$. Source: FAOSTAT

\section{Top ten rice producers}

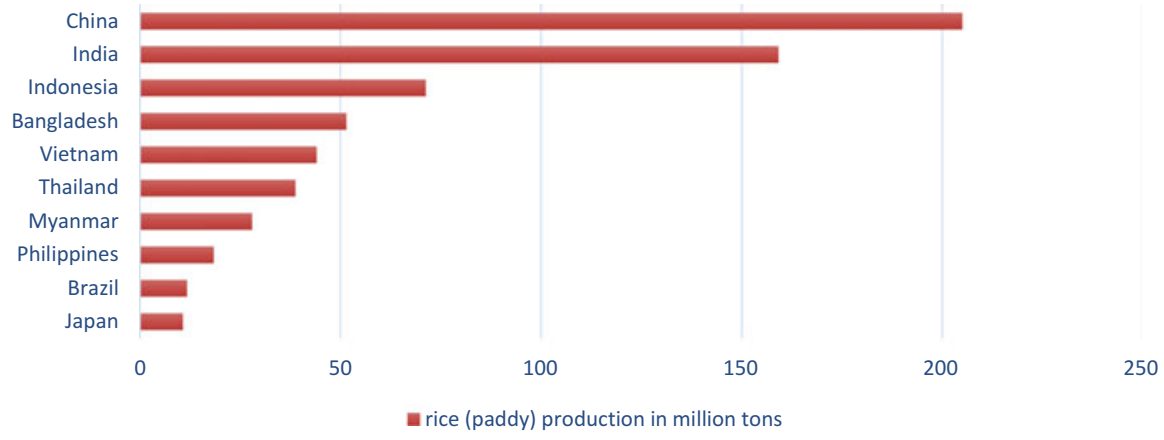

Fig. 17.2 World's rice production in 2013. Source: FAOSTAT

cereals. The countries rely heavily on import for their supply of these commodities. Most Southeast Asians eat rice as their main staple food. Rice constitutes more than half of the population's total calorie intake from cereal. In Thailand and Vietnam, rice accounts even for more than two-third of their total calorie intake from cereal. ${ }^{3}$

ASEAN provides a mix of cases. It is home to some of the world's biggest producers, consumers, exporters, and importers of rice at the same time. Thailand and Vietnam are among the biggest rice exporters, whereas Indonesia, Malaysia, and the Philippines are among the biggest rice importers in the world. However, Indonesia and the Philippines, with their goals to achieve self-sufficiency, view trade as the last source of supply, making them occasional rice importers depending on their production level. Other countries such as Singapore and Brunei are considered as traditional purchasers of rice (Fig. 17.2).

${ }^{3}$ Own calculation based on FAOSTAT data. The shares are among cereals, in 2012. 


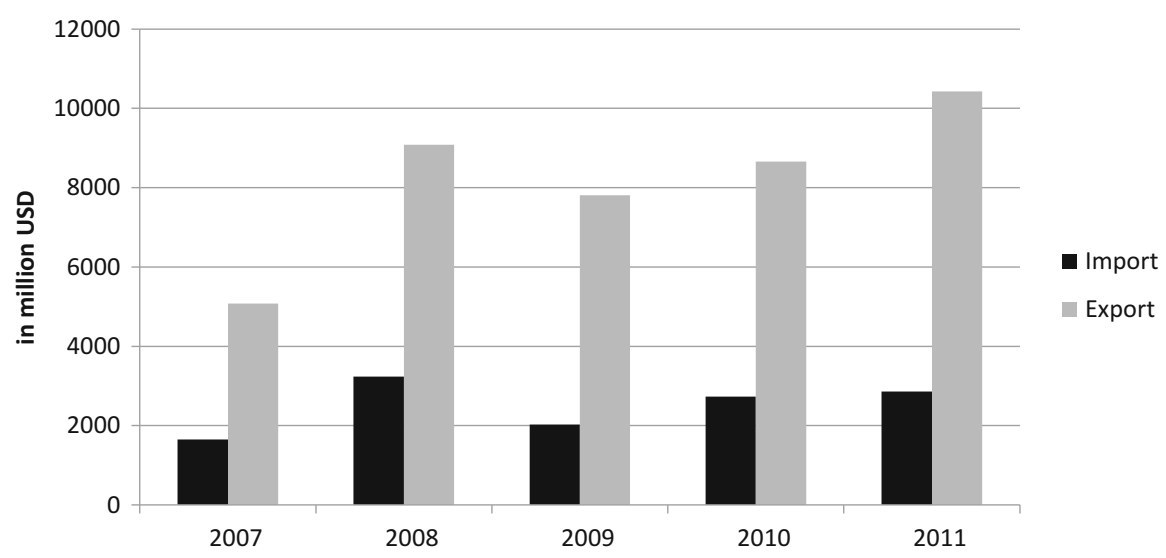

Fig. 17.3 ASEAN rice trade 2007-2011. Source: FAOSTAT

Table 17.1 ASEAN rice

trade balance 2011 (million USD)

\begin{tabular}{l|r|l|l}
\hline Country & Import & Export & Net import \\
\hline Brunei & 39.6 & 2.0 & 37.6 \\
\hline Myanmar & 1.6 & 98.5 & -96.9 \\
\hline Indonesia & 1513.2 & 0.8 & 1512.3 \\
\hline Cambodia & 4.9 & 107.9 & -103.1 \\
\hline Lao PDR & 9.8 & $\mathrm{NA}$ & $\mathrm{NA}$ \\
\hline Malaysia & 606.1 & 0.4 & 605.7 \\
\hline Philippines & 383.2 & 1.7 & 381.5 \\
\hline Singapore & 284.3 & 52.6 & 231.6 \\
\hline Thailand & 8.9 & 6507.5 & -6498.6 \\
\hline Vietnam & 1.3 & 3656.8 & -3655.5 \\
\hline
\end{tabular}

Source: FAOSTAT

The international rice market has been historically thin and unstable (Dawe and Timmer 2012). The geographic concentration of rice production and the thinness of international rice trade with high transactions costs are among the factors contributing to its instability. Only about $5 \%$ of the total global rice production enters the international market, which is mostly concentrated in Asia. Southeast Asia as a region is a net rice exporter (Fig. 17.3), but the bulk of the countries are rice importers (Table 17.1).

ASEAN countries' imports are mainly sourced from within the region. The countries in this region absorb roughly one-third of the total regional exports and send the excess rice supply to the rest of the world (Fig. 17.4).

The average rice tariff rates of ASEAN countries are relatively high compared with other commodities. In 2012, the tariff for rice was $15.94 \%$ on average among ASEAN countries, which was much higher than the total average tariff rates for all commodities (Table 17.2). 


\section{ASEAN rice export destination}

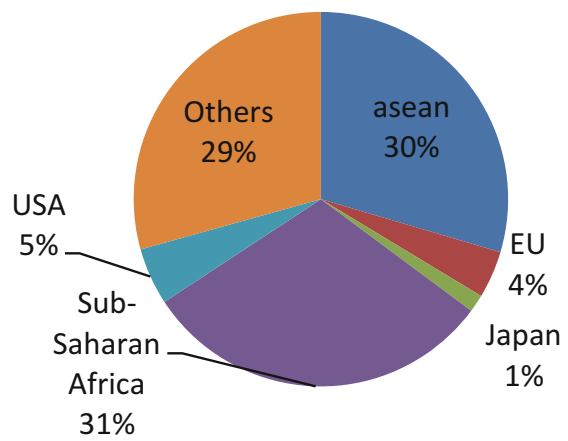

\section{ASEAN rice import source}

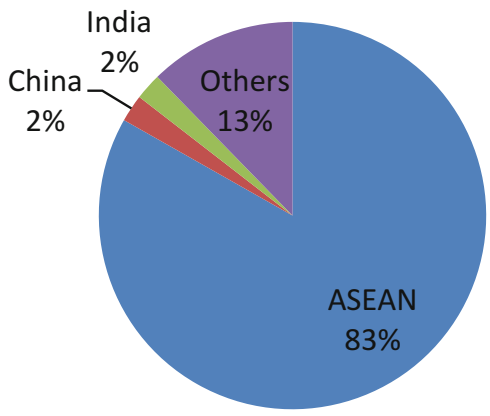

Fig. 17.4 ASEAN rice trade flow 2011. Source: UN COMTRADE

Table 17.2 Average tariff rates of ASEAN countries' in $2012(\%)$

\begin{tabular}{l|c}
\hline Sector & Tariff rates \\
\hline All commodities & 5.42 \\
\hline Food commodities & 7.01 \\
\hline Rice & 15.94 \\
\hline
\end{tabular}

Source: TRAINS database accessed via WITS Note: Average tariff rates not weighted, classification based on standard product in SITC

Southeast Asian countries liberalize their markets through regional and multilateral trade agreements. The cooperation through ASEAN started in 1967, and all ASEAN members are currently also members of the World Trade Organization (WTO). Through the ASEAN Trade in Goods Agreement (ATIGA), which supersedes the Common Effective Preferential Tariff (CEPT) scheme implemented in 1992, international trade within the region is almost without tariffs except for certain sensitive commodities. In addition to bilateral cooperation between ASEAN members and many other countries, the members also build cooperation with neighboring countries while maintaining ASEAN centrality (Fig. 17.5). There are AK-FTA (with Rep. Korea), AC-FTA (with China), AANZFTA (with Australia and New Zealand), and AI-FTA (with India). Although the agreement of ASEAN and Japan has not yet entered into force, many ASEAN members have already established bilateral agreement with Japan. Furthermore, Regional Comprehensive Economic Partnership (RCEP), which will combine ASEAN and their six partners, is currently under negotiation. ${ }^{4}$ ASEAN itself is entering a new phase of stronger cooperation through the ASEAN Economic Community (AEC) in 2015.

\footnotetext{
${ }^{4}$ RCEP participating countries are ASEAN countries (Brunei, Burma, Cambodia, Indonesia, Laos, Malaysia, Singapore, Thailand, Philippines, Vietnam) plus their six partners (Australia, China, India, Japan, New Zealand, and South Korea), launched in November 2012.
} 


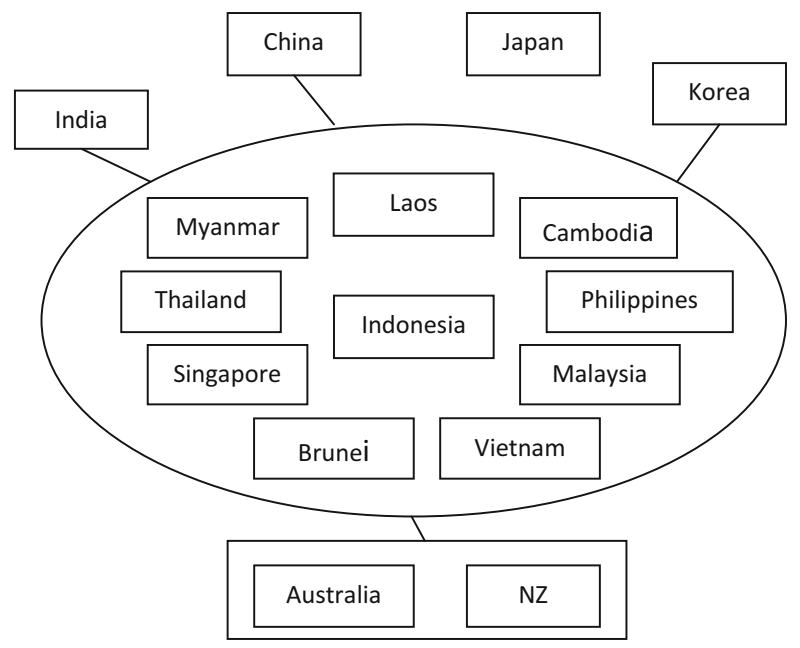

Fig. 17.5 ASEAN free trade agreement. Source: WTO

Table 17.3 Tariff of selected agricultural product of different trade agreement regimes 2012 (\%)

\begin{tabular}{l|l|l|l|l|l|c}
\hline Commodity & MFN applied & ATIGA & AKFTA & ACFTA & AANZFTA & AIFTA \\
\hline Animals \& product & 4.6 & 0.0 & 0.1 & 0.0 & 0.8 & 2.2 \\
\hline Dairy products & 5.4 & 0.0 & 0.0 & 0.0 & 0.8 & 2.2 \\
\hline Fruit, vegetables, \& plants & 5.3 & 0.0 & 0.1 & 0.0 & 1.2 & 3.8 \\
\hline Coffee \& tea & 6.4 & 0.0 & 0.0 & 0.0 & 0.4 & 4.3 \\
\hline Cereals & 11.8 & 7.1 & 7.3 & 7.3 & 7.7 & 10.1 \\
\hline Oil seeds, fats, \& oils & 4.3 & 0.0 & 0.0 & 0.0 & 0.1 & 2.3 \\
\hline Sugar & 12.8 & 8.1 & 8.1 & 8.1 & 8.1 & 10.4 \\
\hline Cotton & 4.0 & 0.0 & 0.0 & 0.0 & 0.0 & 1.6 \\
\hline Other agriculture products & 4.1 & 0.0 & 0.0 & 0.0 & 0.1 & 2.4 \\
\hline
\end{tabular}

Source: WTO. Note: $M F N$ most favoured nations, ATIGA ASEAN Trade in Goods Agreement, AK FTA ASEAN Korea FTA, AC FTA ASEAN China FTA, AANZFTA ASEAN Australia New Zealand FTA, AI FTA ASEAN India FTA

However, despite having significantly reduced their tariffs on many commodities through trade agreements among ASEAN members (and plus countries), considerably high cereals tariffs are still in place (Table 17.3). Cereal products, especially rice, are considered highly sensitive commodities in ASEAN, and thus ASEAN countries still make exceptions by not reducing the tariff on these commodities. 


\subsection{National Food Reserves in Southeast Asia}

The fact that the international rice market has been historically thin and unstable forced countries in this region to prevent the transmission of world price fluctuations to domestic markets (Dawe and Timmer 2012; Rashid et al. 2007). Storage-based public intervention policies have been part of their development agenda for many years to control food availability in the market.

Food price stabilization in the Philippines is managed by the National Food Authority (NFA), which acts as a regulator as well as a corporation engaged in grain trading. The history of the NFA started in the 1960s, when the RICOB and the RCA were still active. In 1972, the National Grains Authority (NGA) replaced these two agencies to promote the integrated growth and development of the grain industry in the country. In 1981, the NGA was transformed to the NFA, and the new organization has two primary mandates: ensuring food security and stabilizing the supply and price of rice. This highlighted the importance of rice in the society. The NFA aimed to fulfill its mandates through procurement, distribution, importation, and buffer stock activities. For the buffer stock activities, the NFA is required to maintain rice stocks which are equivalent to 15 days of consumption for the entire country in its warehouses (Aquino et al. 2013).

In Indonesia, price stabilization was managed by BULOG, a national food reserve agency created in 1967 with the special objective to protect Indonesian domestic markets from sharp price fluctuations on world markets. BULOG buys excess rice production that is not absorbed by the market during harvest seasons from farmers, keeps the rice in its warehouses throughout the country, and distributes the rice at low prices during planting seasons, drought, or other conditions that may cause sharp increases in market rice prices. BULOG maintains a ceiling price policy to ensure the affordability of rice for low-income consumers, especially those living in urban areas. Like the NFA in the Philippines, BULOG also monopolizes rice imports in Indonesia.

As rice importers, Indonesia and the Philippines mainly control rice imports. Other countries, such as Vietnam, which is an exporter country, also use public reserve policies to control rice exports. VINAFOOD in Vietnam is responsible for managing rice availability and rice prices in the market.

\subsubsection{Benefits and Costs of National Reserves}

Although it is difficult to separate the contributions of policies, we have provided some reviews and discussions on the costs and benefits of national food reserve using qualitative approaches. Rashid et al. (2007) argued that storage-based pricestabilization policies benefit countries through price stability and better agricultural performance. Southeast Asian countries were among those that successfully 


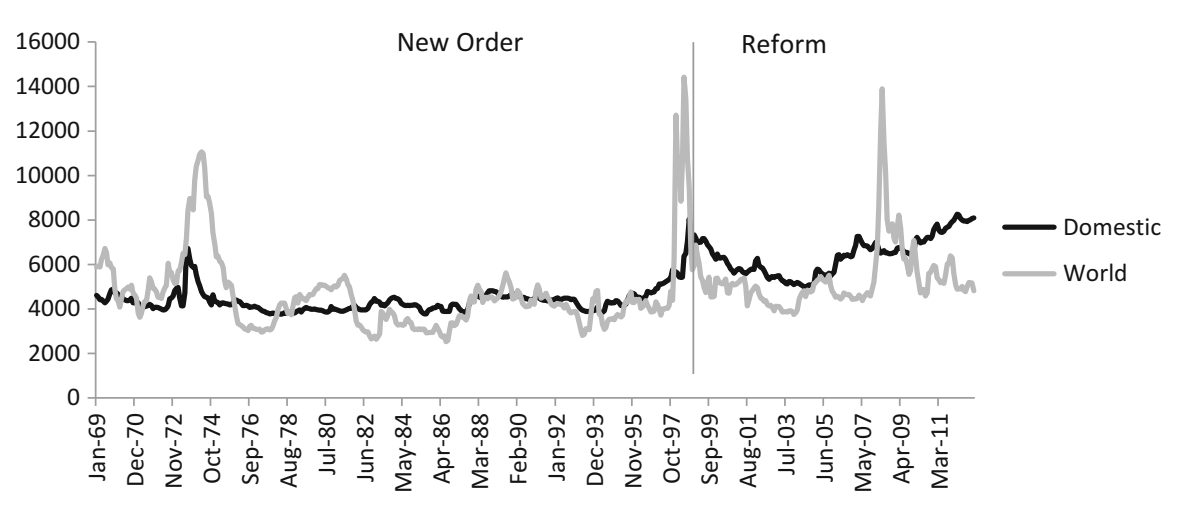

Fig. 17.6 Rice prices in Indonesia during "New Order" and "Reform." Source: Dawe (2008) and GIEWS

managed their domestic food prices for years. Under the "New Order," Indonesia was one of the success stories of food price stabilization, especially for rice. From 1969 to 1997 , domestic rice prices were substantially less volatile than in the "reform" period after 1998, when BULOG has less power to intervene in the market $^{7}$ (see Fig. 17.6). In Vietnam, agricultural policies introduced in the early phase of the unification of North and South Vietnam have transformed the country with disappointing agricultural production to one of the biggest rice exporters in the world.

Price stability benefits consumers and producers at the same time (Timmer 1989). Poor consumers in Southeast Asia, like many others in developing countries, spend more than half of their income on food (von Braun and Tadesse 2012). Excessive price volatility and spikes can cause food and nutrition insecurity for those consumers who cannot maintain consumption stability. Reducing food and nutrition intake, even only temporarily, can have short- and long-term effects (Block et al. 2004). Price-stabilization policy serves as a preventive program instead of a response program for emergency cases. This kind of policy can help consumers better manage their expectations on food prices and thus better manage their food and nutritional intake. Price stability also helps producers maintain consumption stability because most farmers in Southeast Asia are also categorized as poor citizen living in rural areas.

Furthermore, price stability allows farmers to better manage price expectations on food crops, which can enhance efficiency in the farming sector through better management of planting systems. Moreover, price stability contributes to social and

\footnotetext{
5"New Order" refers to the government lead by President Soeharto, in power from 1967 to 1998. 6 "Reform" refers to democratization era in Indonesia after the lost power of Soeharto regime in 1998.

${ }^{7}$ Empirical test using standard deviations of log of prices in difference (SSD) shows 0.05 for the periods before 1998 and 0.1 for the periods after 1998 .
} 
political stability. Arezki and Brückner (2014) showed that price movements can induce political instability, which is manifested in political riots and civil conflicts. Sociopolitical instability can in turn make it difficult for governments to promote growth and development.

Food price stability is in fact associated with the rapid economic growth during the early development phase in Southeast Asia (Dawe and Timmer 2012; Cummings et al. 2006). However, the downside of stabilization policies are that the fiscal costs of public reserves are often high, while the benefits may not be as high as expected. In the Philippines, for instance, the government spending on the NFA surpassed its spending on agrarian reform, research and development, and extension services during the period of 2003-2008 (Aquino et al. 2013). In Indonesia, a financial audit report by Arthur Anderson covering the period from April 1993 to March 1998 suggested that total inefficiency of BULOG was about US\$400 million per year (Arifin 2008). Likewise, the economic costs of distorting market and crowding out private storage and trade can also be very high.

Over decades, there have been several shifts in the price-stabilization policies in Southeast Asia. In the 1980s and 1990s, public reserves fell out of favor particularly because of the changing interest of many countries, which wanted to improve market efficiency. Fiscal difficulties caused by the Asian crisis in the late 1990s triggered countries in the region to intervene less in the market. Indonesia loosened its monopolistic structure and created competition within the domestic market. BULOG lost its domestic power to monopolize the sugar and rice trade because Indonesia was required to comply with the International Monetary Foundation (IMF) Letter of Intent by liberalizing its market.

\subsection{Regional Food Reserve Cooperation}

Following the global food price crisis in 2008, ASEAN countries agreed on the ASEAN Integrated Food Security (AIFS) framework, which aimed to address four major components of the food security challenges: food security arrangements and emergency short-term relief, sustainable food trade development, integrated food security information system, and agricultural innovation. The AIFS framework provides the foundation for the establishment of the APTERR, an ASEAN regional reserve cooperation together with its three partners. ${ }^{8}$ The APTERR was finally agreed upon in October 2011 and entered into force in July 2012.

The history of the APTERR dates back to 1979, when the original members of ASEAN $^{9}$ agreed on the ASEAN Emergency Rice Reserve (AERR). The objective was to build up physical rice reserves that would serve the needs of member countries when the demand in any member country cannot be fulfilled from own

\footnotetext{
${ }^{8}$ China, Japan, and Rep. Korea.

${ }^{9}$ Five original members are: Indonesia, Malaysia, Philippines, Singapore, and Thailand; current ASEAN members also include Brunei, Cambodia, Laos, and Vietnam.
} 
production or through purchases in international market. The main reason for the cooperation was that the ASEAN countries identified food instability as a common threat and as the consequence of the high vulnerability of the region's food production. The AERR was created with the initial earmarks of 50,000 tons of rice as a subset of national stocks. Releases from the AERR were to be arranged through bilateral negotiation between a country in a state of emergency and a country offering its earmarked reserve. The system, however, was never used, and the amount of rice in the reserve was too undersized to cope with an actual emergency.

The efforts of building up stocks in the region continued. In 2001, ASEAN countries, in partnership with China, Japan, and Korea, initiated a consultation and cooperation process in establishing an emergency rice reserve at the regional level. A pilot project of the East Asia Emergency Rice Reserve (EAERR) was created at the end of 2003 with the political support of the ASEAN Plus Three countries. The purpose of the EAERR is twofold: maintaining food security in case of emergency and contributing toward price stability in the region (APTERR 2014). The food price crisis in 2008 led the ASEAN Plus Three governments to strengthen the financial and stockpiling abilities of the EAERR and move beyond the project beyond its pilot phase. The APTERR was finally agreed upon as a permanent scheme in October 2011 and entered into force in July 2012.

The initial earmarked stock of the APTERR is 787,000 tons of rice, which were voluntarily contributed by the member countries (Table 17.4). The stocks remain owned and controlled by the respective governments for meeting the needs of any other member countries in case of emergency. The governments are also responsible for the management cost of their earmarked stocks to ensure the stocks remain in

Table 17.4 Earmarked stock of APTERR

\begin{tabular}{l|l}
\hline Country & Earmarked stocks (tons) \\
\hline \multicolumn{2}{l|}{ ASEAN countries } \\
\hline Brunei Darussalam & 3000 \\
\hline Cambodia & 3000 \\
\hline Indonesia & 12,000 \\
\hline Lao PDR & 3000 \\
\hline Malaysia & 6000 \\
\hline Myanmar & 14,000 \\
\hline Philippines & 12,000 \\
\hline Singapore & 5000 \\
\hline Thailand & 15,000 \\
\hline Vietnam & 14,000 \\
\hline Plus Three countries \\
\hline China & 300,000 \\
\hline Japan & 250,000 \\
\hline Korea & 150,000 \\
\hline Total & 787,000 \\
\hline
\end{tabular}

Source: APTERR 
good quality. Another type of APTERR stock is a stockpiled emergency rice reserve, which could be in form of cash or rice, but is owned collectively by APTERR member countries and managed by the APTERR secretariat under the supervision of the APTERR council. ${ }^{10}$

The APTERR is designed to mainly address emergency situations anywhere in the region. Emergency is defined as "the state or condition having suffered extreme and unexpected natural or man-induced calamity, which is unable to cope with such state or condition through its national reserve and is unable to procure the need through normal trade." 11 In principle, given the definition of emergency, extreme price volatility is not a reason for releasing rice from the APTERR.

The APTERR presents itself as a subset of national reserves. Rice release from the APTERR is only possible when a national reserve is unable to cope with extreme shocks. The release of APTERR stock is based on the request of the member country which encounters an emergency rice shortage. The requesting country is also responsible for the transportation and operational costs incurred during the stock release.

The APTERR heavily relies on the commitment and political will of every member country, without any sanction mechanism in place. Nevertheless, APTERR member countries appoint a Management Team to ensure rice releases take place in case of emergency.

\subsubsection{The Benefits and Costs of Regional Reserves}

There have been extensive debates on storage-based price-stabilization policies (Galtier 2013). On the one hand, countries with public reserve policies can benefit from price stability and better agriculture performances, which are associated with economic success. On the other hand, the policies are often criticized for their high fiscal and economic costs.

National public food reserves in Southeast Asia are largely managed as buffer stocks to address price instability. The size of national public food reserves is usually large, and their stocks are frequently rotated to maintain the quality of the stocks. Consequently, the fiscal costs of storing food/grains are high, and the potential of creating market distortion is high as a result of the high degree of intervention. On the other hand, an emergency public reserve usually holds a low amount of stocks and is only intended for addressing humanitarian needs rather than for price stabilization.

In the competitive storage model, the central idea behind storing food today for tomorrow's consumption is based on the assumption that an equilibrium price can be reached when today's price $\left(p_{t}\right)$ equals the expected price tomorrow $\left(p_{t+1}\right)$ plus the costs of storage. Stocks are held in anticipation of profit, which implies that the

\footnotetext{
${ }^{10}$ The APTERR council is composed of one representative from each APTERR member country.

${ }^{11}$ ASEAN Integrated Food Security Framework.
} 
marginal gain of holding stocks should exceed the marginal cost. However, under this condition, the optimal stock level is not necessarily optimal from the social welfare perspective.

Using this assumption, public involvement in stockholding is needed to address the economy-wide consequences of demand or supply shocks. Difficulties arise when determining the optimal stock level (Gardner 1979) as it depends on the criterion of desirability. For instance, public rice stocks maintained by the NFA in the Philippines are equivalent to 15-day consumption needs of the entire country (Aquino et al. 2013). This stock level is determined based on the assumption that the national stock level (public and private) should be equivalent to the 90-day consumption needs, which covers the lean season, when usually no harvests from domestic production prevail.

Notwithstanding the difficulties in determining the optimal stock level, we provided an illustration on how regional cooperation can significantly reduce the required stocks. ${ }^{12}$ Following Kornher and Kalkuhl (2014), we estimated the required stocks as the difference between the largest historic supply shortfall and the percentage of threshold:

$$
S=\max \left[\left(1-\frac{x}{100}\right) E\left(Q_{t}\right)-Q_{t}\right]
$$

where $x$ is the level of allowed supply shortfall. For instance, if we want to maintain $97 \%$ consumption stability, then the allowed supply shortfall is $3 \%$. $E\left(Q_{t}\right)$ is the expected supply level at time $t$. Since supply for consumption increases with population growth, we measured shortfall around a trend.

Supply shortfalls of countries individually were compared with the total supply shortfalls of the entire region using the coefficient of variation of supply, which can be written as:

$$
\mathrm{CV}^{2}\left(\sum_{1}^{n} Q_{i}\right)=\sum_{1}^{n} s_{i}^{2} \mathrm{CV}\left(Q_{i}\right)+2 \sum_{1}^{n} \sum_{i+1}^{n} s_{i} s_{i}+1 r_{i, i+1} \operatorname{CV}\left(Q_{i}\right) \operatorname{CV}\left(Q_{i+1}\right)
$$

where $\mathrm{CV}^{2}\left(\sum_{1}^{n} Q_{i}\right)$ is the coefficient of variation of the regional supply, and $Q_{i}$ is the supply of each country. $s_{i}$ and $r_{i, i+1}$ are a country's share and coefficient of correlation, respectively. This condition assumes that there is free flow of food between the countries within the region. Production shortfall can be compensated by imports, which means that the supply shortfall in one country can be compensated by supply surpluses in other countries.

\footnotetext{
${ }^{12}$ Further discussion on optimal stock level can be found in Kornher and Kalkuhl (2014).
} 
Table 17.5 Stocks required for allowed supply shortfall of $3 \%$ (tons)

\begin{tabular}{|c|c|c|c|c|c|c|}
\hline & \multicolumn{2}{|c|}{ w/o cooperation } & \multicolumn{2}{|c|}{ With cooperation } & \multicolumn{2}{|c|}{ Actual APTERR stock } \\
\hline & $\begin{array}{l}\text { Required } \\
\text { stock }\end{array}$ & $\begin{array}{l}\text { Stock-to-use } \\
\text { ratio }\end{array}$ & $\begin{array}{l}\text { Required } \\
\text { stock }\end{array}$ & \begin{tabular}{|l|} 
Stock-to-use \\
ratio
\end{tabular} & $\begin{array}{l}\text { Earmarked } \\
\text { stock }\end{array}$ & $\begin{array}{l}\text { Stock-to-use } \\
\text { ratio }\end{array}$ \\
\hline \multicolumn{7}{|l|}{ ASEAN } \\
\hline Brunei & 1227 & 23.22 & 688 & 13.02 & 3000 & 56.76 \\
\hline Cambodia & 47,768 & 12.95 & 26,799 & 7.27 & 3000 & 0.81 \\
\hline Indonesia & 57,413 & 1.05 & 32,210 & 0.59 & 12,000 & 0.22 \\
\hline Lao PDR & 18,912 & 10.73 & 10,610 & 6.02 & 3000 & 1.7 \\
\hline Malaysia & 17,947 & 5.59 & 10,069 & 3.14 & 6000 & 1.87 \\
\hline Myanmar & 34,552 & 2.37 & 19,385 & 1.33 & 14,000 & 0.96 \\
\hline Philippines & 78,355 & 5.41 & 43,960 & 3.04 & 12,000 & 0.83 \\
\hline Singapore & 10,420 & 23.28 & 5846 & 13.06 & 5000 & 11.17 \\
\hline Thailand & 130,132 & 8.60 & 73,008 & 4.82 & 15,000 & 0.99 \\
\hline Vietnam & 136,657 & 5.42 & 76,669 & 3.04 & 14,000 & 0.55 \\
\hline \multicolumn{7}{|l|}{ Plus Three } \\
\hline China & 678,268 & 3.2 & 380,533 & 1.8 & 300,000 & 1.42 \\
\hline Japan & 132,280 & 8.7 & 74,214 & 4.88 & 250,000 & 16.45 \\
\hline Korea & 59,788 & 6.93 & 33,543 & 3.90 & 150,000 & 17.40 \\
\hline Total & $1,403,717$ & 3.81 & 787,535 & 2.14 & 787,000 & 2.14 \\
\hline
\end{tabular}

Source: Own elaboration based on USDA PSD. Note: required stocks w/o cooperation and with cooperation are calculated for 2 months consumption

Considering that not all of ASEAN countries are rice producers, supply data (production + imports) was used instead of production data only. Rice supply in Singapore, for instance, relies heavily on imports. Using the actual rice supply data of ASEAN+3 countries from the USDA PSD for the period of 1980-2014, we estimated the required stocks for the 2-month consumption stability at $97 \%$ (allowed supply shortfall of $3 \%$ ). Countries' stocks were determined from the regional stocks using their consumption shares. The results of the estimations are presented in Table 17.5. ${ }^{13}$

The simulations showed that regional cooperation can significantly reduce the required rice stock by roughly $44 \%$, from $1,403,717$ to 787,535 tons. This implies that the fiscal costs associated with holding stocks can be reduced through cooperation and risks sharing. The simulations also showed that all countries can reduce the required contributions of stocks through regional risk sharing.

In the APTERR system, stocks remain owned and controlled by the respective governments for the purpose of meeting the needs of any other APTERR member countries when they experience an emergency. However, transportation costs arise when transferring rice from a donor country to a country in need. This transportation costs should also be taken into consideration when calculating the cost reduction

\footnotetext{
${ }^{13}$ Correlation matrix of supply shortfall, maximum shortfall, average annual supply, and consumption shares that were used for the estimations are available in Appendix.
} 
Table 17.6 Storage and transportation cost (million USD)

\begin{tabular}{l|l|l|l|l|l|l}
\hline & \multicolumn{2}{|l|}{ Storage cost } & \multicolumn{2}{l|}{ Transportation cost } & \multicolumn{2}{l}{ Total cost } \\
\cline { 2 - 8 } & Low & High & Low & High & Low & High \\
\hline w/o cooperation & 35 & 49 & - & - & 35 & 49 \\
\hline With cooperation & 20 & 28 & 0.7 & 1.1 & 20.7 & 29.1 \\
\hline Cost savings & & & & & 14.3 & 19.9 \\
\hline
\end{tabular}

Source: own elaboration. Note: Storage cost is estimated in the range of US $\$ 25$ (low) to US\$35 (high) per ton. Transportation cost within ASEAN+3 countries is estimated in the range of US\$10 (low) to 15 (high) per ton

resulting from cooperation. Since transportation costs arise only when a country within the region experiences a shortfall, we calculated the transportation costs from the expected trade volume ${ }^{14}$ in times of shortfall, which was estimated to be equal to the required stocks for 2 months consumption. The results are available in Table 17.6. ${ }^{15}$

The total cost saving through food reserve cooperation was estimated to be about US\$14.3-19.9 million when storing enough food to satisfy consumption for 2 months. The saving is roughly $40 \%$ of the estimated cost without cooperation.

The current APTERR stock is roughly equal to the total stocks needed by the region to maintain consumption stability at $97 \%$ for 2 months. However, the voluntary contribution of each member country of the APTERR is not the same as the required stock for each country with cooperation through risks sharing. For instance, Japan and Korea contribute more than what they need, but Cambodia and Lao PDR contribute less than their required stocks. Richer countries of the APTERR are more likely to provide food assistance to their poorer neighboring countries. This can be seen also from the voluntary contributions of APTERR member countries: each of the "Plus Three" countries contributes more than the total contribution from all ASEAN countries. There is a strong indication that the large contribution from the "Plus Three" countries has brought APTERR into practice. Its predecessor, the AERR, which consisted only of ASEAN members with small size of stock, had never released its stock during its entire operational period.

We also conducted a simulation to determine the required stock for ensuring consumption stability of $97 \%$ in different cooperation regimes in order to analyze whether countries benefit from larger cooperation (Table 17.7). Through our simulation of three scenarios-ASEAN, ASEAN+3, and ASEAN+3 plus Indiawe found that the benefits of cooperation decreased when more countries joined the cooperation. This is possible because the correlation of shortfall risks increases with the increasing number of member countries. However, although the benefits of cooperation were decreasing, the required stock was still significantly reduced.

\footnotetext{
${ }^{14}$ The expected trade volume in times of shortfall is based on the mean value of the historical regional shortfalls.

${ }^{15}$ Numbers of supply shortfall for each country are available in Appendix.
} 
Table 17.7 Stocks required for allowed supply shortfall of $3 \%$ in different (tons)

\begin{tabular}{l|c|l|l}
\hline $\begin{array}{l}\text { Regional cooperation } \\
\text { (simulation) }\end{array}$ & $\begin{array}{l}\text { Required stocks without } \\
\text { cooperation }\end{array}$ & $\begin{array}{l}\text { Required stocks with } \\
\text { cooperation }\end{array}$ & Reduced by (\%) \\
\hline ASEAN & 533,382 & 178,885 & 66 \\
\hline ASEAN+3 & $1,403,717$ & 787,535 & 44 \\
\hline ASEAN+3+India & $2,362,418$ & $1,637,777$ & 31 \\
\hline
\end{tabular}

Source: Own elaboration based on USDA PSD

For instance, if India also joined the ASEAN +3 cooperation, the required stock would be reduced by $31 \%$. Moreover, larger cooperation means larger coordination between countries, which can potentially prevent collective action failures.

\subsection{WTO Rules on Public Reserve}

The central issue in a WTO-compatible framework for developing countries, including those in Southeast Asia, is whether these countries are able to stockpile their staple food (i.e., rice) to ensure stable incomes for their farmers while ensuring that their low-income citizens are able to access the basic food at an affordable price. This issue, however, affects or has the potential to affect other countries. The potential spillovers of public reserves are high in different member countries due to different conditions of countries in ensuring food security for the citizens. The increasing demand for food for stockholding purposes increases prices and potentially reduces supply for immediate consumption in other countries. When food stocks are finally released for consumption, international trade can be distorted, affecting market competition.

The present WTO rules allow member countries to maintain or introduce domestic support measures without any limitations or reduction commitments. To qualify for this, domestic support to food reserves must meet "the fundamental requirement that they have no, or at most minimal, trade distorting effect or effects on production." 16 Countries, however, may argue the definition of minimal trade distorting effects.

A public reserve is not only economically complex but also politically encumbered. The Bali Package, which has been mentioned as the first-ever agreement reached in the history of the WTO, still makes an exception for public stockholding. In the 9th ministerial meeting held in Bali, Indonesia, at the end of 2013, the WTO member countries adopted an interim solution and agreed to negotiate a permanent solution that would specifically address public reserve by the 11th

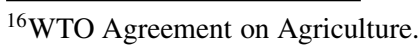


ministerial conference in 2017. Furthermore, in the Post-Bali work, countries also agreed to continue with the interim solution if the permanent solution cannot be agreed upon by 2017. This means that no agreement has been reached for a public reserve. Nevertheless, the interim solution, which should prevent countries from challenging other countries through dispute settlement mechanism until a permanent solution is found, can be a starting point for a new institutional arrangement to prevent collective action failures of uncoordinated national public reserves, which can further destabilize prices at the international level.

\subsection{Conclusion and Policy Implication}

Public food reserve policies have been used by many countries for decades. Although in the 1980s and 1990s, public reserves fell out of favor with many countries particularly against the backdrop of changing interest, with the countries turning their attention to improving market efficiency, the policy has always been part of the development agenda of many countries. Storage-based stabilization policy through public food reserve is receiving much more attention today in the era of increasing food price volatility. Food security concerns in the recent years have led many countries to reconsider using public food reserve as the main policy to deal with such uncertainty and price instability.

ASEAN countries have provided an interesting case with their long experience in implementing storage-price-based stabilization policies. Despite the difficulties in measuring the impact of different policies, price stabilization has been an integral part of the development agenda of ASEAN countries for decades and has contributed to price stability, which is associated with the economic successes in this region. ASEAN also has shown that cooperation at the regional level is possible. The APTERR presents itself as a regional effort to face the common challenges of ensuring food security.

One of the main concerns regarding public reserve is that the fiscal cost of storing food is relatively high. The cost, however, can be reduced with cooperation. The simulations have shown that regional cooperation significantly reduces the required stocks, which in turn reduces the costs of holding them. Even when transportation cost arising because of decentralized storage in the different countries is taken into account, the total cost for food reserve with cooperation is still lower than without cooperation. This definitely will be beneficial for all participating countries. Admittedly, determining the optimal stock level is difficult. It always depends on the criterion of desirability. The current earmarked stock of the APTERR is designed mainly to address emergency situation rather than for price stability. However, it may have a calming effect on the market and thereby prevent the rapid increase in food prices. 
ASEAN and their partner countries can also consider expanding their cooperation to include other neighboring countries. The simulation which considered India as the "fourth" country showed that such cooperation would still significantly reduce the required stocks that will be beneficial for all member countries involved. India was emphasized in the simulation because of its important role in the region. The fact that the country is home to around 200 million undernourished people ${ }^{17}$ has brought serious concerns to the policymakers in the country. With the world's largest food programs covering public procurement, storage, and distribution of wheat and rice, India has successfully stabilized its food prices for many years. However, the policies give rise to very high fiscal cost. In 2013, the cost is estimated to be around $1.2 \%$ of the country's GDP (Kozicka et al. 2015).

While India is not part of ASEAN Plus Three countries food reserve cooperation, ASEAN and India have already signed an FTA, which has been in force since January 2010. The countries involved could also consider including food reserve as part of their cooperation which will likely be beneficial to all the participating countries. In addition to reducing the overall fiscal costs, larger cooperation and coordination also mean that collective action failures are diminished.

Learning from ASEAN case, public food reserve is an ancient idea that is still relevant today. The way forward is to build institutional arrangements that facilitate coordination and cooperation among countries through various channels, including the multilateral trading system of the WTO. Each of the ASEAN trade agreements with six countries ${ }^{18}$ which could be deepened under the RCEP framework, which combines all ASEAN "plus" agreements together, and this could be a starting point for a stronger and larger cooperation in various areas, including public reserves.

Acknowledgments The authors are grateful for the financial support of the Federal Ministry of Economic Cooperation and Development of Germany (BMZ) within the research project "Volatility in Commodity Markets, Trade Policy, and the Poor" and the European Commission (FoodSecure Research Project).

\section{Appendix}

\footnotetext{
${ }^{17}$ Estimated from $17 \%$ of population as stated in the Global Hunger Index, IFPRI et al. (2014).

${ }^{18}$ The six countries are Australia, China, India, Japan, Korea, and New Zealand.
} 


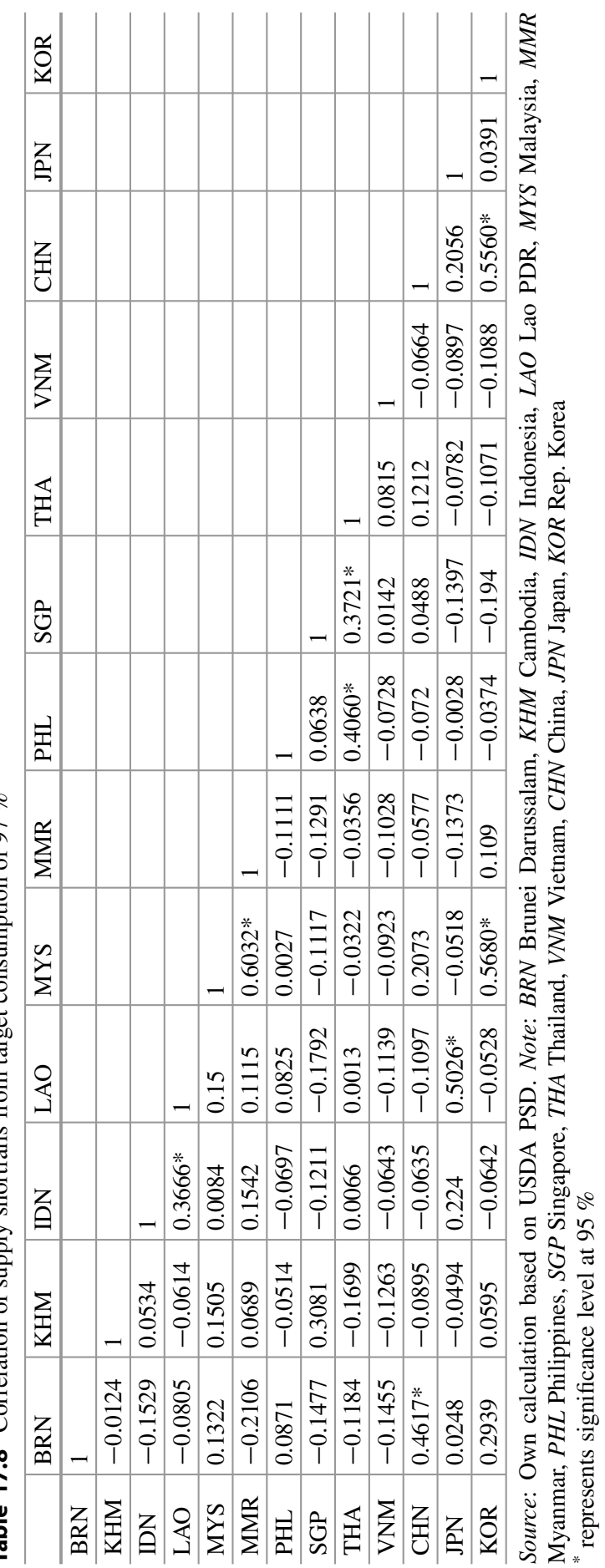




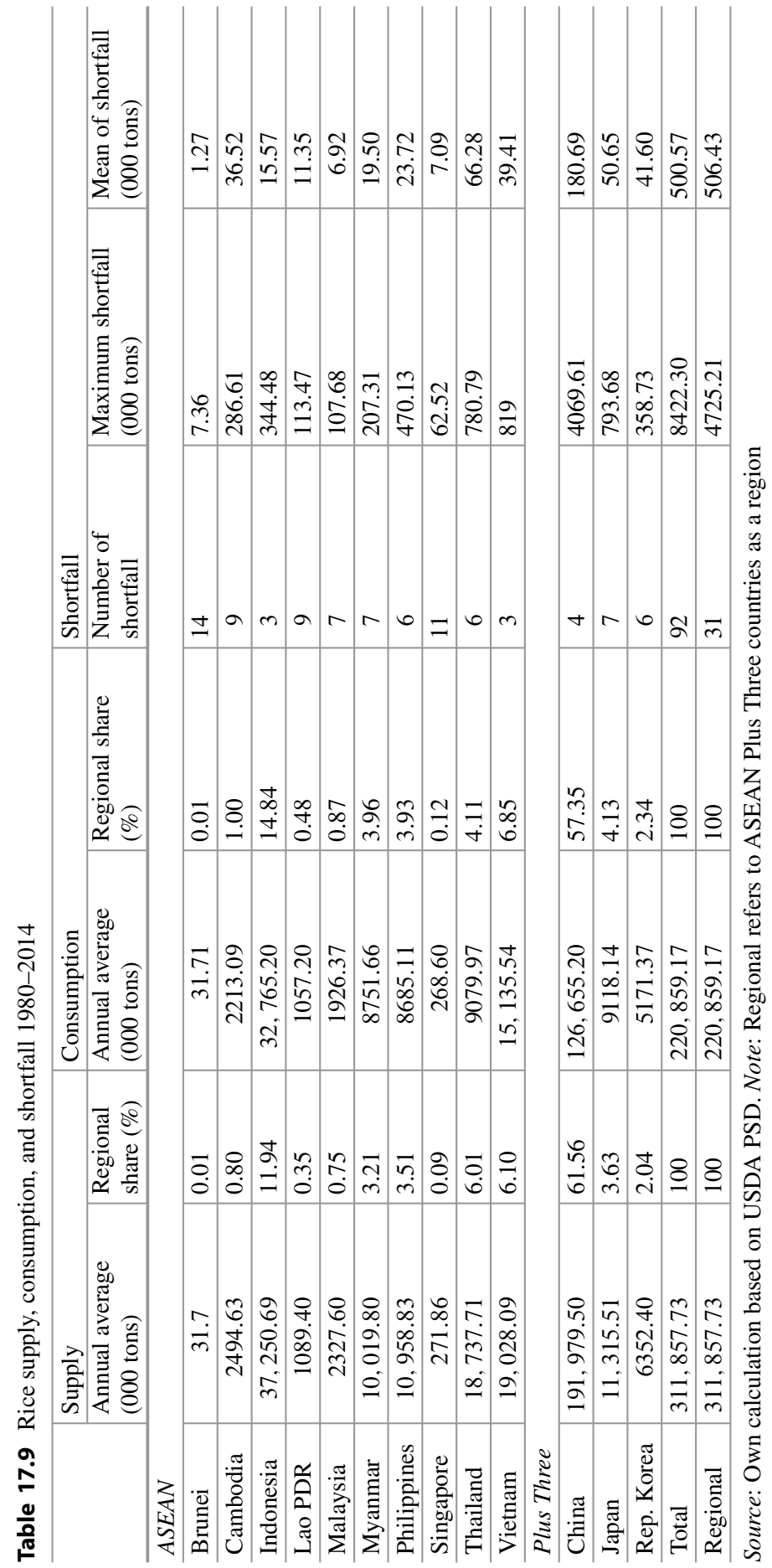


Open Access This chapter is distributed under the terms of the Creative Commons AttributionNoncommercial 2.5 License (http://creativecommons.org/licenses/by-nc/2.5/) which permits any noncommercial use, distribution, and reproduction in any medium, provided the original author(s) and source are credited.

The images or other third party material in this chapter are included in the work's Creative Commons license, unless indicated otherwise in the credit line; if such material is not included in the work's Creative Commons license and the respective action is not permitted by statutory regulation, users will need to obtain permission from the license holder to duplicate, adapt or reproduce the material.

\section{References}

Abbott P (2010) Stabilization policies in developing countries after the 2007-2008 crisis. In: Global forum on agriculture policies for agricultural development, poverty reduction and food security, 29-30 November, OECD, Paris

Anderson K (2012) Government trade restrictions and international price volatility. Global Food Secur 1:157-166

Aquino A, Daquio CRO, Ani PAB (2013) National Food Authority: it's role in price stability and food security. Asia-Pacific Information Platform on Agricultural Policy

Arezki R, Brückner M (2014) Effects of international food price shocks on political institutions in low-income countries: evidence from an international food net-export price index. World Dev $61: 142-153$

Arifin B (2008) From remarkable success stories to troubling present: the case of BULOG in Indonesia. In: Rashid S, Gulati A, Cummings R Jr (eds) From parastatals to private trade: lessons from Asian agriculture. IFPRI, Washington, DC

ASEAN Plus Three Emergency Rice Reserve (APTERR). Available at http://www.apterr.org. Accessed 23 Aug 2014

Block SA, Kiess L, Webb P, Kosen S, Moench-Pfanner R, Bloem MW, Timmer CP (2004) Macro shocks and micro outcomes: child nutrition during Indonesia's crisis. Econ Hum Biol 2:21-44

Briones RM, Durant-Morat A, Wailes EJ, Chavez EC (2012) Climate change and price volatility: can we count on the ASEAN Plus Three Emergency Rice Reserve? ADB sustainable development working paper series, 24

Cummings R (2012) Experience with managing food grains price volatility in Asia. Global Food Secur 1:150-156

Cummings R, Rashid S, Gulati A (2006) Grain price stabilization experiences in Asia: what have we learned? Food Policy 31:302-312

Dano E (2006) ASEAN's emergency rice reserve schemes: current developments and prospects for engagements. Women in action no. 3

Dawe D (2001) How far down the path to free trade? The importance of rice price stabilization in developing Asia. Food Policy 26(2):163-175

Dawe D (2008) Can Indonesia trust the world rice market? Bull Indones Econ Stud 44(1):115-132

Dawe D, Timmer P (2012) Why stable food prices are a good thing: lessons from stabilizing rice prices in Asia. Global Food Secur 1:127-133

Food and Agriculture Organization (FAO), Statistic Division. FAOSTAT. Available at http:// faostat3.fao.org/download/T/*/E. Accessed 23 Aug 2014

Galtier F (2013) Managing food price instability: critical assessment of the dominant doctrine. Global Food Secur 2:72-81

Gardner BL (1979) Optimal stockpiling of grain. Lexington Books, Lexington, MA

Gilbert C (2012) International agreements to manage food price volatility. Global Food Secur $1: 134-142$

Headey D (2011) Rethinking the global food crisis: the role of trade shocks. Food Policy 36:136146 
International Food Policy Research Institute (IFPRI), Weltungerhilfe and Concern Worldwide (2014) Global hunger index: the challenge of hidden hunger. IFPRI, Washington, DC

Islam N, Thomas S (1996) Food grain price stabilization in developing countries: issues and experiences in Asia. IFPRI, Food Policy Review Series, Washington, DC

Jha S, Srinivasan P (1999) Grain price stabilization in India: evaluation of policy alternatives. Agric Econ 21(1):93-108

Kornher L, Kalkuhl M (2014) Cost and benefit assessment of regional storage cooperation. In: ZEF-IFPRI workshop on food price volatility and food security, Bonn, October 2014

Kozicka M, Kalkuhl M, Brockhaus J (2015) Food grain policies in India and their implications for stocks and fiscal costs: a partial equilibrium analysis. In: ECOMOD conference paper, Chestnut Hill, MA, USA, 15-17 July 2015

Rashid S, Cummings RJ, Gulati A (2007) Grain marketing parastatals in Asia: results from six case studies. World Dev 35(11):1872-1888

Timmer CP (1989) Food price policy: the rationale for government intervention. Food Policy 14:17-27

Timmer CP, Dawe D (2007) Managing food price instability in Asia: a macro food security perspective. Asian Econ J 21(1):1-18

United States Department of Agriculture (USDA), Production, Supply and Distribution online. Available at https://apps.fas.usda.gov/psdonline/. Accessed 23 Aug 2014

von Braun J, Tadesse G (2012) Global food price volatility and spike: an overview of costs, causes, and solutions. ZEF discussion papers on development policy, 161

von Braun J, Torero M (2008) Physical and virtual global food reserves to protect the poor and prevent market failure, June, IFPRI, Policy brief 4

Wright B (2009) International grain reserves and other instruments to address volatility in grain markets. Policy research working paper 5028. World Bank, Washington, DC 